\title{
Elements Boosting on Employees' Performance in Sabah Oil Palm Estate
}

Rayner Marcus, Farahida Zulkefli, Ismail Rakibe, Mohd Nizar Khairuddin, Shafiq Sani and Syahrizan Syahlan

To Link this Article: http://dx.doi.org/10.6007/IJARBSS/v11-i9/10187

DOI:10.6007/IJARBSS/v11-i9/10187

Received: 13 July 2021, Revised: 20 August 2021, Accepted: 30 August 2021

Published Online: 17 September 2021

In-Text Citation: (Marcus et al., 2021)

To Cite this Article: Marcus, R., Zulkefli, F., Rakibe, I., Khairuddin, M. N., Sani, S., \& Syahlan, S. (2021). Elements Boosting on Employees' Performance in Sabah Oil Palm Estate. International Journal of Academic Research in Business and Social Sciences, 11(9), 1681-1691.

Copyright: (c) 2021 The Author(s)

Published by Human Resource Management Academic Research Society (www.hrmars.com)

This article is published under the Creative Commons Attribution (CC BY 4.0) license. Anyone may reproduce, distribute, translate and create derivative works of this article (for both commercial and non-commercial purposes), subject to full attribution to the original publication and authors. The full terms of this license may be seen

at: http://creativecommons.org/licences/by/4.0/legalcode

Vol. 11, No. 9, 2021, Pg. 1681 - 1691

Full Terms \& Conditions of access and use can be found at http://hrmars.com/index.php/pages/detail/publication-ethics 


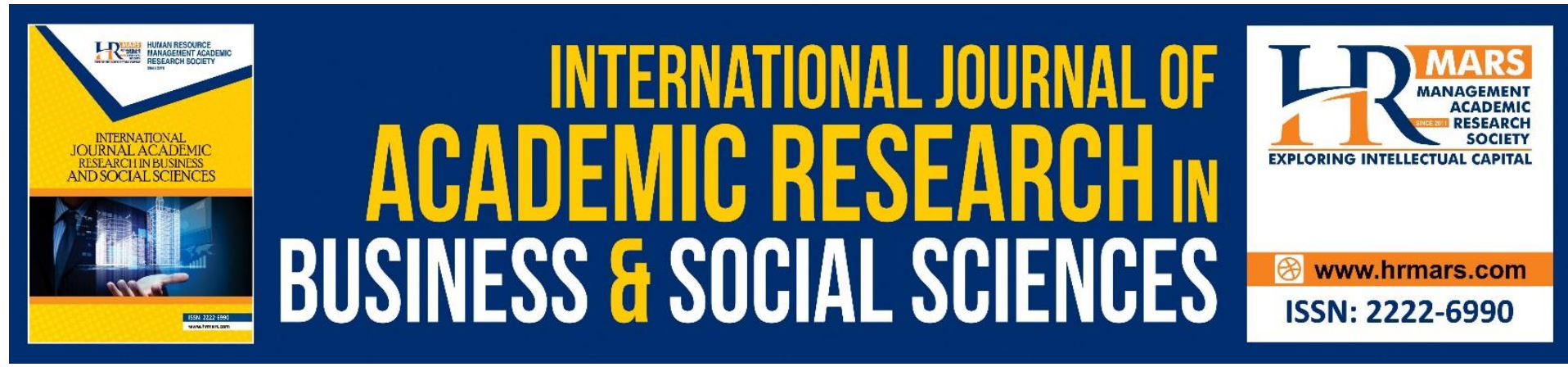

\title{
Elements Boosting on Employees' Performance in Sabah Oil Palm Estate
}

\author{
Rayner Marcus ${ }^{1}$, Farahida Zulkefli ${ }^{1}$, Ismail Rakibe ${ }^{1}$, Mohd Nizar \\ Khairuddin ${ }^{2}$, Shafiq Sani ${ }^{1}$ and Syahrizan Syahlan ${ }^{1}$ \\ ${ }^{1}$ Faculty of Plantation and Agrotechnology, Universiti Teknologi MARA (UiTM), Jasin 77300, \\ Melaka Malaysia, ${ }^{2}$ FGV R\&D Sdn Bhd, Tun Abdul Razak Agricultural Research Centre, 26400 \\ Bandar Pusat Jengka Pahang Malaysia \\ Email: syahrizan@rocketmail.com
}

\begin{abstract}
Performance measurement has become very important and popular for industries which vital in oil palm estate as it the ways to better decision making in managements. The aim of this paper is to investigate the most dominant element in influencing the employee's performance. In this survey, the elements are salary, amenity, and technical training. This study was involved 105 workers that works at Kota Marudu, Sabah. The data has been collected through structural distribution close ended questionnaire. Then being analysis using SPSS. The analysis. The result show that factor of employees' performance were salary, safety, amenities, and training. The most dominant factor is training which affecting their performance with Beta value is 0.301 . It shows that the training is the most important in increase their performances. Despite the above limitations, we believe that this study provides a contribution to the literature. In addition, the results of the study will provide a better understand the concept of employee's productivity. The findings reported here can be used by the estate managers to be more particular to all these factors especially salary. Wages or salaries must be competitive as compared with other economic sector and commensurate with the nature of plantation work, which is quite heavy, difficult, dangerous, and challenging. In the current situation, wage of RM1,100 is no longer appropriate
\end{abstract}

Keywords: Factors, Employees' Performance, Salary, Safety, Amenities, Training, Oil Palm And Estate.

\section{Introduction}

Malaysia's employees performance went up in the 2020 compared to year 2019 according to figures from the Department of Statistics Malaysia. Malaysia measures its employee performance in two points of view. The first is measured by value added per hour worked. The second way is expressed as the ratio of value added to employment. Employee performance by hours worked for Agriculture sector increased 1.9 per cent in 2020 with a RM26 per hour. The growth was mainly supported by the better productivity of Crops \& Livestock and Forestry \& Logging. Meanwhile, employee performance by employment plunged 1.8 per cent with level RM53,235 per person. Due to Covid - 19, Malaysia facing 
workers shortage especially harvesters around 31,000 (MPOB, 2020). Malaysia is struggling to attract new expatriate workers and retain those already active in the sector. Even the local youth also have a negative perception working in oil palm estate. Oil palm plantation companies must counter this for the workers to give out more for the sake of their employer. Given the demanding nature of the job, the inhospitable living conditions and low wages, plantation companies find it difficult to recruit workers. Majority about 85 per cent of employees in oil palm plantations in Malaysia are from Indonesia, Bangladesh, Nepal, Cambodia and India. In some plantations, there are also Rohingya workers. The purpose of this paper is to highlight some areas where plantation companies could make improvements in their continuing quest to make work on plantations more humane, rewarding and welcoming (Farahida et al., 2020). Working atmosphere at the plantations are hard and the living environment is uninviting. It is not surprising that Malaysians are generally not prepared to work on the plantations. Raising labour productivity, therefore, seems to be the only way to solve the problem of a tight labour market because the supply is not able to fulfill the demand for labour in the oil palm plantation sector. In the oil palm industry, and especially in the plantation sector, monitoring labour productivity is most crucial in ensuring that the industry remains competitive in the global market and continues to be among the main contributors to GNI.

The purpose of this study is:

1. To investigate the relationship between the elements (salary, amenities, safety and technical training) and employees' performance.

2. To determine the most influencing factor in boosting the employee performance.

\section{Review Literature}

In the following section, this paper presents the literature describing the hypothesized relationships among various variables of this study

\section{Labour Productivity}

Performance of workers is about their efficiency as well their productivity towards organizational objective goals and achievements. Thus, improving employees' performance is importance as it can contribute the success of an organizational. Learning organizations play important role in enhancing employee performance through providing trainings and developments for their employee (Dahkoul, 2018). On average, one worker in the plantations (at the field level) in Malaysia produced $174 \mathrm{mt}$ FFB per year. On a regional basis, labour in Peninsular Malaysia was more productive as compared with the other regions. One worker in Peninsular Malaysia produced about $199 \mathrm{mt}$ FFB per year compared with 161 and $156 \mathrm{mt}$ per year in Sarawak and Sabah, respectively A FFB harvester and collector in Peninsular Malaysia produced a total of $437 \mathrm{mt}$ FFB per year, higher than in the other regions (MPOB, 2018).

\section{Salary}

Base on Farahida et al study in 2020, the current situation, wage of RM1,100 is no longer appropriate. Considering the cost of living is rising every day, the rate of wages can be categorized as very low especially for the local workers. Method of daily wages which is normally implemented in the oil palm plantation resulted in low income compared to the manufacturing industry. 
Safety

In MSPO principal 4 state that the management shall provide the appropriate personal protective equipment (PPE) at the place of work to cover all potentially hazardous operations as identified in the risk assessment and control such as Hazard Identification, Risk Assessment and Risk Control (HIRARC). Management shall establish Standard Operating Procedure for handling of chemicals to ensure proper and safe handling and storage in accordance to Occupational Safety Health (Classification Packaging and Labeling) Regulation 1997 and Occupational Safety Health (Use and Standard of Exposure of Chemical Hazardous to Health) Regulation 2000.

\section{Amenities}

Maimunah (2018) stated that productivity techniques will only flourish in organization which has a positive climate. Working conditions, such as salary and overall environment are important indicators of employment satisfaction and engagement (Hermsen and Rosser, 2008). According to (Kumaran Kolandai, Sanath 2019). The MSPO Standards set out the general principles for certification requirements for smallholder oil palms, plantations and palm oil processing's facility to ensure that palm oil is produced in a responsible and sustainable manner In addition, in order to promote the adoption of MSPO certification, the Malaysian Government has made available financial assistance covering MSPO audit fees for smallholders, growers and processing facilities.

\section{Technical Training}

Training is a learning process and is an integral part of the development of human resources. According to (Abbas, 2014) the training is a major element for workers in the success of business, related to the lack of knowledge and skills of certain workers and the inability to execute tasks on a timely basis. Che Zhen et. al (2021), stated that pest control technology and soil management technology been well accepted by the household with a more technical training.

\section{Materials and Methods}

Based on prior studies the following conceptual model has been developed to illustrate the impact of salary, safety, amenities and technical training on employee performance (Figure 1)

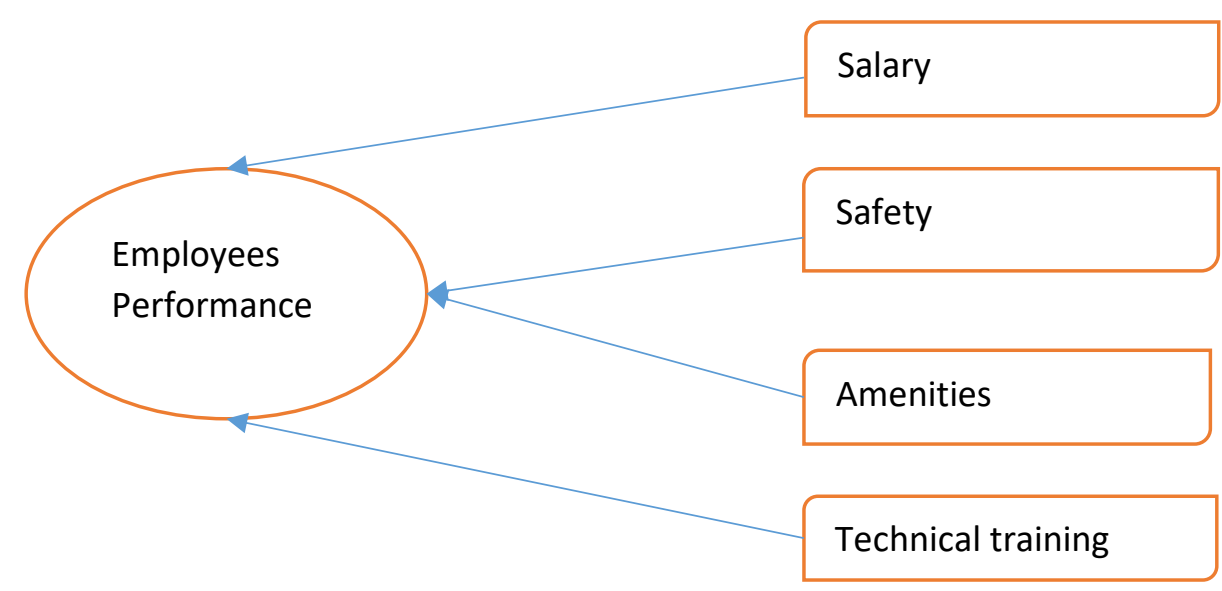

Figure 1: Conceptual framework of elements that influencing employee performance 


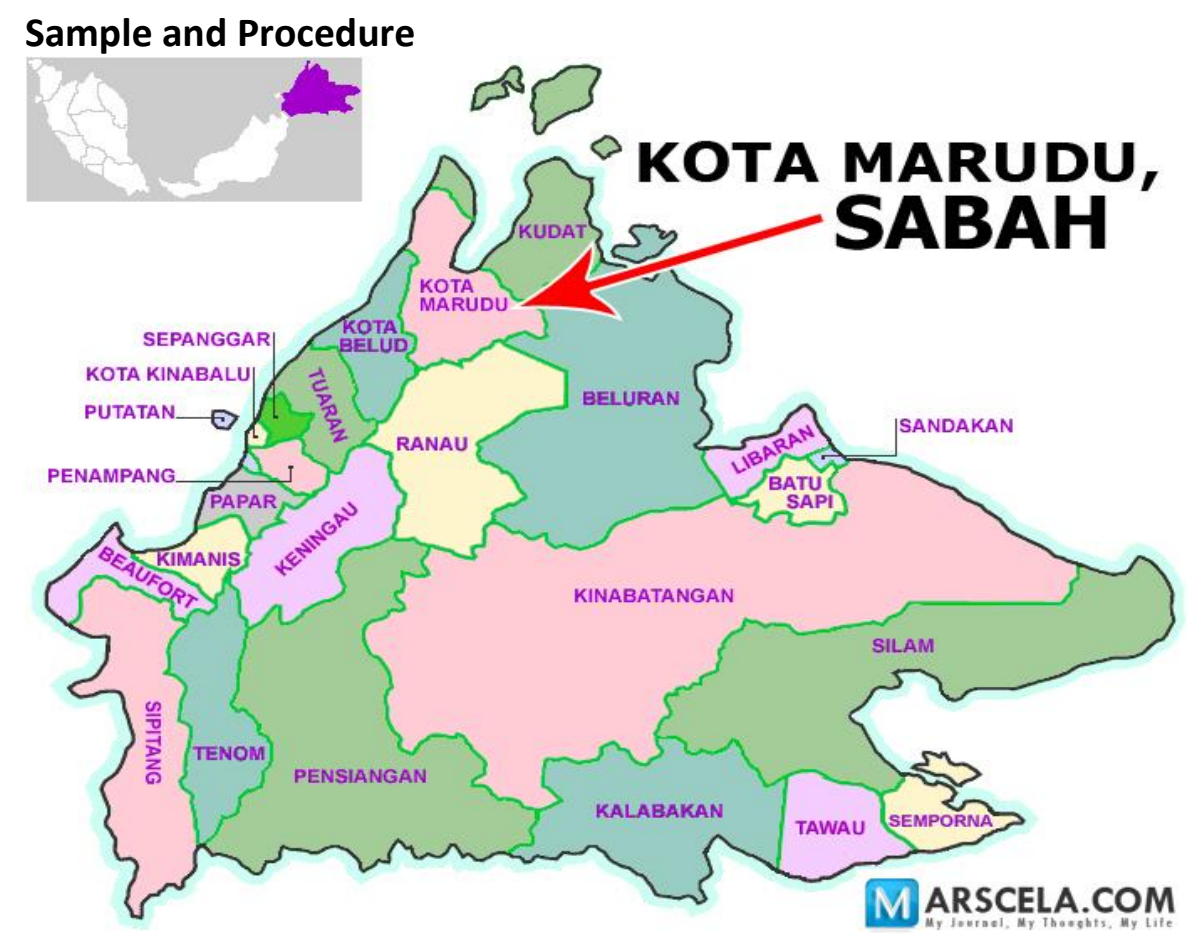

Figure 2: Location of study

For this study the employees at Kota Marudu of Oil Palm Estate Sabah were questioned. In all, the target population numbered 150 individuals. Of this number, 108 respondents were sampled using Krejcie and Morgan (1970) formula for sample size determination. Ultimately, 105 questionnaires (97 per cent) were collected from respondents from the total of 108 given out. During data collection, the researcher distributes the questionnaire and gathers the data by face to face with the employees. By using this technique, the researcher has several advantages such as the researcher need a short period of time to collect the data as well as the researcher also can clarify the respondent problem about the questionnaire distributed on the spot. The researcher also may have advantages to elaborate more about the case study topics and make the respondent well understand before them answering the questionnaire. To ascertain the sample size from the different types of works (harvesting, fertilizer, spraying, maintenance, and mandore), this study adopted stratified random sampling. The primary objective was to ensure a fair representation of employees was drawn from each types of work. This was made more easily attainable by using a sampling frame containing the names of the employees in each nature of work. Having this frame in place, the researchers relied on the lottery method of simple random sampling to select the respondents from each stratum (type) of the frame. Simple random sampling was used with the intent of giving every employee an equal chance of being selected. However, critical and ardent consideration was attached to ethics such as privacy, confidentiality and voluntary participation. Table I presents the biographical profile (including gender, age groups, total length of service, citizenship, educational status, type of workers, salary total hours work per day) of the respondents.

\section{Results and Discussion}

Reliability Test

Internal consistency estimates were formulated using Cronbach's alpha coefficients. From table 1, the results of Cronbach's alpha show a positive consistency on the data if Cronbach's Alpha values ranging from 0.70 to 0.80 (Andy Field, 2017). This shows that the study based on 
the questionnaire is fit for this study. A maximum alpha value of 0.90 has been recommended (Green et al, 1977). It is suggested the alpha is too high that some items are redundant as they are testing the same question but in a different guise.

Table 1: Reliability Test (Mohsen Tavakol and Reg Dennick, 2011)

\begin{tabular}{lll}
\hline Variables & Cronbach's Alpha & Internal consistency \\
\hline Salary & 0.777 & Acceptable \\
Safety & 0.690 & Acceptable \\
Amenities & 0.762 & Acceptable \\
Technical training & 0.782 & Acceptable \\
Performance & 0.727 & Acceptable
\end{tabular}

Descriptive Analysis

The biographical information of the respondents is presented in table 2. Table 2 reveals the result of the biographical information of the respondents. The highest number of age among the respondent in the sample come from age 20 to 30 years old $(54 \%)$, followed by age between 31 to 40 years old (34\%). The lowest percentage in the sample is more than 50 years old (4\%). Employee's gender shows that the male gender is the majority with $78 \%$ (82 respondents), on the other hand, only $22 \%$ ( 23 respondents) is a female workers. In term of nationality, approximately $40 \%$ (42 respondents) of the respondents are local, and the rest $60 \%$ being heavily depend on expatriate from Indonesia. Further profiling of the respondents showed that $86(82 \%)$ respondents of this survey possessed 1 to 5 years years working experience, meanwhile $19(18 \%)$ respondents has working experience more than 5 years. Most of the respondents have no formal academic background or certificate which is 38 (36\%) respondents, followed by secondary school which is $29(28 \%)$ respondents and primary school have accounted $21(20 \%)$ respondents. With regard the job title occupied in the estate, the largest group of respondents are harvesters with 36 respondents (34\%), followed by sprayers $15(15.5 \%)$ respondents, with staff $4 \%$ being the smallest number. 
Table 2: Biographical information of respondents

\begin{tabular}{|c|c|c|c|}
\hline Demographic variables & Response categories & Frequency & $\%$ \\
\hline \multirow[t]{2}{*}{ Gender } & Male & 82 & 78 \\
\hline & female & 23 & 22 \\
\hline \multirow[t]{4}{*}{ Age (years) } & $20-30$ & 57 & 54 \\
\hline & $31-40$ & 36 & 34 \\
\hline & $41-50$ & 8 & 8 \\
\hline & More than 50 & 4 & 4 \\
\hline \multirow[t]{2}{*}{ Marital Status } & Single & 15 & 14 \\
\hline & married & 90 & 86 \\
\hline \multirow[t]{5}{*}{ Educational Level } & Primary school & 21 & 20 \\
\hline & Secondary school & 29 & 28 \\
\hline & Diploma & 13 & 12 \\
\hline & Degree & 4 & 4 \\
\hline & No education & 38 & 36 \\
\hline \multirow[t]{4}{*}{ Income } & Less than RM1000 & 21 & 20 \\
\hline & RM1,001 - RM2,000 & 59 & 56 \\
\hline & $\mathrm{RM} 2,001-\mathrm{RM} 3,000$ & 21 & 20 \\
\hline & More than RM3,001 & 4 & 4 \\
\hline \multirow[t]{2}{*}{ Nationality } & Malaysia & 42 & 40 \\
\hline & Indonesia & 63 & 60 \\
\hline \multirow[t]{2}{*}{ Working experience } & 1-5 year & 86 & 82 \\
\hline & $6-10$ year & 19 & 18 \\
\hline \multirow[t]{7}{*}{ Job position } & Supervisor & 13 & 12 \\
\hline & Mandore & 11 & 10 \\
\hline & Staff & 4 & 4 \\
\hline & Harvester & 36 & 34 \\
\hline & Driver & 11 & 10 \\
\hline & Sprayer & 21 & 20 \\
\hline & Field workers & 11 & 10 \\
\hline
\end{tabular}

\section{Relationship between Factors Contributed to employee productivity}

Pearson Correlation Analysis was used to identify the relationship between the independent variables (salary, safety, amenities and technical training) that affect the dependent variable (employee performance). Theoretically, the higher value of the correlation between two variables, the more related these variables are to each other (these values show the strength of relationships among variables). The direction of relationships among variables is another 
issue that should be considered in analysing the correlations between variables. A positive correlation indicates that the direction of the relationship is positive (if one increases, the other one increases). Bivariate Correlations are used to know the nature, direction and significance of the bivariate relationship of the variables of this study. Therefore, the Bivariate Correlations procedures have used to compute Pearson's correlation coefficient. A rule of thumb is that multicollinearity may be a problem if a correlation is $>.90$, in the correlation matrix formed by all the independent variables (Coakes and Steed, 2000). The correlation value is as presented in Table 2 below: -

Table 3: Correlation value Interpreted according to Hinkle, Wiersma and Jurs (2003)

\begin{tabular}{l} 
Correlation \\
\hline .90 to 1.00 \\
.70 to .90 \\
.50 to .70 \\
.30 to .50 \\
.00 to .30 \\
0
\end{tabular}

Relationship Strength

Very high positive correlation

High positive correlation

Moderate positive correlation

Low positive correlation

Little if any correlation

No relationship

Table 3: Analysis of a Correlation between salary, safety, amenities, technical training and employees performance.

\section{Employees performance}

\begin{tabular}{llll}
\hline Factors & $\begin{array}{l}\text { Significant } \\
(\boldsymbol{p})\end{array}$ & $\begin{array}{l}\text { Correlation } \\
\text { value } \\
(\boldsymbol{r})\end{array}$ & Relationship strength \\
\hline Salary & 0.014 & $0.344^{*}$ & Positive Moderate \\
Safety & 0.960 & -0.007 & Negative low \\
Amenities & 0.001 & $0.439^{* *}$ & Positive Moderate \\
Technical training & 0.001 & $0.467^{* *}$ & Positive Moderate \\
$* *$ Correlation is significant at the 0.01 (two-tailed) &
\end{tabular}

The results of correlation analysis in table 3 reveals that there is positive and significant relationship of employee performance with salary, amenities and technical training. The technical training had the highest $r$ value $(0.467)$, it means when the salary increase the workers performance also increase. Moreover, amenities $(r=0.439)$ and salary $(r=0.344)$ were also depicts significantly moderate positive correlated to employee performance. Only safety had a negative low $r$ value (-0.007). Findings provided enough evidence to suggest that there was a relationship between these constructs and employee performance. It can be documented that employee performance increases in presence of these three elements (salary, amenities and technical training).

Coefficient of determination

Table 4: Model of summary

\begin{tabular}{lllll}
\hline Model & $\mathbf{R}$ & $\mathbf{R}^{\mathbf{2}}$ & Adjusted $\mathbf{R}^{\mathbf{2}}$ & Std. Error of the Estimation \\
\hline 1 & 0.662 & 0.386 & 0.332 & 0.44112
\end{tabular}


$R^{2}$ value is said to be strong when in explaining the variation of the independent variables on the dependent variable the value is between 0 (zero) and 1 (one). According to Table 4, the Coefficient of determination $\left(R^{2}\right)$ was 0.386 ; meaning that all the 4 variables can explain its effect on employee performance in Oil Palm Estate Kota Marudu Sabah equal to $39 \%$. The remaining $61 \%$ was influenced by other factors that are not been investigated, or out of this research framework. These findings are consistent with the predicted relationships and provide support to our conceptual framework.

Multiple Linear Regressions analysis

Table 5: Results of multiple regression analysis

\begin{tabular}{|c|c|c|c|c|c|c|c|}
\hline \multicolumn{3}{|c|}{$\begin{array}{l}\text { Unstandardized } \\
\text { coefficients }\end{array}$} & \multicolumn{3}{|c|}{ Standardized coefficients } & \multicolumn{2}{|c|}{$\begin{array}{l}\text { Collinearity } \\
\text { Statistics }\end{array}$} \\
\hline Model & $B$ & $\begin{array}{l}\text { Standar } \\
\text { d error }\end{array}$ & $\beta$ & $t$ & $\begin{array}{l}\text { significanc } \\
\text { e }\end{array}$ & Tolerance & VIF \\
\hline Salary & 0.168 & 0.081 & 0.253 & 2.075 & 0.044 & 0.917 & 1.090 \\
\hline Safety & -0.199 & 0.199 & -0.205 & -1.666 & 0.103 & 0.901 & 1.110 \\
\hline Amenities & 0.299 & 0.129 & 0.304 & 2.318 & 0.025 & 0.794 & 1.259 \\
\hline $\begin{array}{l}\text { Technical } \\
\text { training }\end{array}$ & 0.301 & 0.110 & 0.355 & 2.734 & 0.009 & 0.809 & 1.236 \\
\hline
\end{tabular}

Next, multiple regression analysis was applied to see which factor impact employee productivity. Regression analysis aids to measure the relative strength of independent variable on dependent variable. Due to three predictors are correlated, multicollinearity have to be diagnosed using tolerance and Variance inflation factors (VIF). Values of VIF that exceed 10 and tolerance below 0.25 are regarded as multicollinearity. It is discovered the regression model is fit. All direct positive relationship between variables and employee's performance were examined using multiple regression analysis to ascertain the extent to which they explain that the variance in employees performance. Two variables significantly impact employee's performance with technical training $(B=0.301)$ providing the largest level of impact and followed by amenities $(B=0.299)$. This indicate that if the rate of each factor increases, then employee performance of Oil Palm Estate Kota Marudu Sabah will also increase.

\section{Conclusion}

Labour performance in oil palm estate Kota Marudu Sabah still second rate from the Malaysia national target. Findings from the study enabled the researcher to identify the major strategies that can be used to push the envelope employees performance. The investigation into the origins of these deficiencies and assessment of their effect could assist in solving the problem. Hence, if the employees have not fully trained in their task it can lead to low productivity because low skill workers tend to make mistake in their task. Ultimately, all the objectives on this study were obtained. The correlation evaluation shown that these three elements have a significant connection toward their performances which is salary, technical training and amenities.

Despite the above limitations, we believe that this study provides a contribution to the literature. In addition, the results of the study will provide a better understand the concept of employee's productivity. The findings reported here can be used by the estate managers to be more particular to all these factors especially salary. Wages or salaries must be 
competitive as compared with other economic sector and commensurate with the nature of plantation work, which is quite heavy, difficult, dangerous, and challenging. In the current situation, wage of RM1,100 is no longer appropriate. Considering the cost of living is rising every day, the rate of wages can be categorized as very low especially for the local workers. Method of daily wages which is normally implemented in the oil palm plantation resulted in low income compared to the manufacturing industry. At present, the government has already implemented and emphasized the minimum monthly wages method, but it is still not competitive with manufacturing sector and has become the second riddle to local. Therefore, adequate and prompt remuneration in addition to appraisal systems embracing quality, schedule milestones and commensurate rewards must be used.

Moreover, overtime work is the common means of schedule acceleration especially during peak season from July until November. In positive climate facet, management should provide a safe and productive environment, provision of amenities such as personal protective equipment (PPE), modern tools, restroom and canteen facilities to lift morale. The manager also should provide transport especially to the workers especially to the harvester. In addition, the study found that the appreciation (reward) was statistically significant and positively related to overall employee productivity. The employees feel happy and being honor when the manager give them a sack of rice, a $1 \mathrm{~kg}$ Milo, $4 \mathrm{~kg}$ of cooking oil and other necessity. Such a study would allow us to determine if some of the issues we observed were a function of HRM practices or a function of the communication of HRM decisions between the field and the back office. This sector must be transformed through several improvements.

\section{References}

Ali, A. L. Z. (2016). The Impact of Motivation on the Employee. International Journal of Academic Research in Business and Social Sciences, 6(9).doi:10.6007/IJARBSS/v6i9/2311

Mahadevan, A. M. H. (2019). 'Impact of Training Methods on Employee Performance in a Direct Selling Organization, Malaysia. IOSR Journal of Business and Management (IOSR-JBM), 21(10), 07- 14. Retrieved from www.iosrjornal.org

Anastasios, D., Diamantidis, P. C. (2019). "Factors affecting employee performance: emprical approach. International Journal of Productivity and Performance Management, 68(1), 171-193. Retrieved from https://doi.org/10.1108/IJPPM- 01-20180012

Bishop, L. (2016). Free and Fair Labor in Palm Oil Production: Principles and. Retrieved from Business \& Human Right Resource Center. Retrieved from https://www.businesshumanrights.org/

Chenghai, Y. (2018). High resolution satellite imaging sensors for precision agriculture. Frontiers of Agricultural Science and Engineering, 5(4). doi:10.15302/J-FASE- 2018226

Dahkoul, Z. M. (2018). The Determinants of Employee Performance in Jordanian Organization. Journal of Economics, Finance and Accounting (JEFA), 5(1), 11 - 17. doi:0.17261/Pressacademia.2018.780

Muda, I. A. R. (2014). Factors Influencing Employees' Performance: A Study on the Islamic Banks in Indonesia. International Journal of Business and Social Science, 5(2).

Latif, M. M. (2019). The Impact Of Training And Development On Employeesâ€ $€^{\mathrm{TM}}$ Performance: An Analysis Of Quantitative Data. Noble International Journal of Business and Management Research, Noble Academic Publshiher, 3(2), 25 33. 
Mansor, N. A. (2016). Palm Oil Sustainability Certification and Firm Perfromance: Is There a Conflict Betwween RSPO and MSPO. The European Confrence on Social Science.

Stephen, EC. M. G. (2020). Impacts of COVID-19 on agricultural and food systems worldwide and on progress to the sustainable development goals. Agricultural Systems, 3. doi:10.1016/j.agsy.2020.102873 